\title{
Front-page illustrations and political powers in Early Modern Spanish journalism
}

\author{
Carmen Espejo-Cala ${ }^{1}$ and Francisco Baena Sánchez ${ }^{2}$ \\ Universidad de Sevilla \\ ${ }^{1}$ e-mail: carmenes@us.es \\ ORCID iD: https://orcid.org/0000-0001-9664-8191 \\ ${ }^{2}$ e-mail: frbaena@us.es \\ ORCID iD: https://orcid.org/0000-0002-5304-7924
}

Submitted: 21 February 2020. Accepted: 28 June 2020.

\begin{abstract}
This paper explores the representation of political powers in the front-page illustrations of Early Modern Spanish newspapers. The knowledge about Early Modern European journalism has undergone a remarkable development in recent decades: however, research on the form of the first newspapers is scarce. The paper presents a corpus of 162 news pamphlets and gazettes published in Seville between 1618 and 1635. An analysis follows considering the presence of engravings on the cover page and their classification. This insight leads to the conclusion that the image did not play a decisive role to draw the attention of readers, even in sensationalist news pamphlets. The illustration is used not to present the events narrated but to stress the genre of the print; about half of the corpus prints have a cover engraving that reproduces a coat of arms, associated with the monarchical power in two thirds of the news sheets: Spanish journalism experienced a growing officialization, prior to the appearance of the first official newspaper of the kingdom, Gazeta Nueva (1661). Also, a small group of news sheets with ecclesiastical or nobiliary coat of arms reveals the interest of local powers in the flourishing of the journalistic market.
\end{abstract}

KEYWORDS: History of Journalism; Images; Newspaper Design; Propaganda; Local Powers; Patronage.

Citation / Cómo citar este artículo: Espejo-Cala, Carmen and Baena Sánchez, Francisco (2021) "Front-page illustrations and political powers in Early Modern Spanish journalism". Culture \& History Digital Journal, 10 (1): e012. https://doi. org/10.3989/chdj.2021.012

RESUMEN: Ilustraciones de portada y poderes políticos en el periodismo español de la Edad Moderna.- Este artículo explora la representación de los poderes políticos en los grabados de portada de los periódicos de la Edad Moderna. Nuestro conocimiento sobre el periodismo europeo de la Edad Moderna ha experimentado un desarrollo notable en las últimas décadas: sin embargo, la investigación sobre la forma de los primeros periódicos es escasa. Presentamos un corpus de 162 relaciones de sucesos y gacetas publicadas en Sevilla entre 1618 y 1635. Se ha realizado un estudio y clasificación de la presencia de grabados en portada, para concluir primeramente que la imagen no jugó un papel decisivo como reclamo, incluso en el caso de las relaciones sensacionalistas. La ilustración no se usa en referencia a los eventos narrados, sino para enfatizar el género del impreso; aproximadamente la mitad de los impresos del corpus tiene un grabado de portada que reproduce un escudo de armas, asociado con el poder monárquico en dos tercios de los casos: el periodismo español experimentó una creciente oficialización, antes de la aparición del primer periódico oficial del reino, la Gazeta Nueva (1661). Además, un pequeño grupo de impresos con escudo de armas eclesiástico o nobiliario revela el interés de los poderes locales en el florecimiento del mercado periodístico.

PALABRAS ClaVE: Historia del Periodismo; Imágenes; Diseño periodístico; Propaganda; Poderes locales; Patronazgo.

Copyright: ( 92021 CSIC. This is an open-access article distributed under the terms of the Creative Commons Attribution 4.0 International (CC BY 4.0) License. 


\section{INTRODUCTION}

More than a decade ago, Broersma claimed that the form and style of newspapers had not received the attention that they deserved in communication history studies. This discipline has traditionally addressed the institutional facets of journalism, such as its political, economic or technological aspects, and-in more recent decades-journalistic practices and the analysis of newspaper content over the ages. It has only been in the past few years that a small number of works have focused on the form of news-its format, design and discursive style-notwithstanding the fact that, in his day, Schudson (1994) drew attention to "the politics of narrative form". Broersma concluded that "studying the emergence and historical development of form and style conventions deepens our understanding of how journalism works" (2007, p. 9). On the other hand, he noted that the study of newspaper form is eminently transnational and comparative, for, while content tends to be unique or circumstantial, the form is universal and complies with conventions and routines accepted in many countries.

Broersma and other authors have studied the formal conventions of the Anglo-American model of journalism, which was developed at the end of the nineteenth century and which spread to other countries at a later date. However, very few studies have focused hitherto on the style and design conventions of journalism in the Early Modern age: after Morison's pioneering work (1932), Brownlees (2011) has analysed the modalities of the news discourse in seventeenth-century England; Conboy (2004) has demonstrated the continuities between the oldest and contemporary formats; Petta (2016) has highlighted the importance of military accounts in the shaping of the first Italian news pamphlets; and Espejo-Cala (2016) has studied the standardisation of the front-page designs of Spanish news pamphlets and gazettes.

Studies of European printing in the Early Modern age have addressed the front-page illustrations of the first newspapers in a very tangential manner, ${ }^{1}$ with the notable exception of the comparative perspective-in the European context - employed by Ettinghausen (2015). As to Spanish specialists, Mínguez (1999) observes that, on the whole, Spanish printing could not compete with its European counterparts either in the quality of their illustrations or in their purely technical or artistic aspects. A shortcoming that would only be compounded in the seventeenth century by the superiority of the Flemish and Italian printers as regards the production of relevant works. ${ }^{2}$ Nevertheless, Mínguez stresses that, by and large, economic constraints only allowed for the inclusion of a sole illustration, generally on the front-page, which implies that a lot of thought went into its selection, in order that it should provide symbolic or contextual elements fundamental for understanding the news in question. The high cost of designing and producing engravings explains why this was usually the responsibility of someone unrelated to the print shop in question - the author or sponsor-who commissioned and paid for them (as will be seen further on, this conclusion drawn by Mínguez may be relevant when applied to the study of Spanish news pamphlets).
Most of the engravings illustrating Spanish news pamphlets were anonymous and produced by artisans belonging to related guilds-silversmiths, for instance-for whom this was not their main occupation. Nonetheless, the occasional collaboration of famous painters like Ribera and Murillo with print shops in their hometowns (in this case, Valencia and Seville, respectively) has been documented. It is not unlikely that those engravings depicting allegorical images, the head portraits of important personages or elaborate coats of arms were, therefore, of cultivated origins, produced by leading artists. But they were subsequently copied time and again by modest authors to be included in broadsheets or other cheap publications (Gallego, 1990).

In this study, we have created a corpus of serial news pamphlets and gazettes published in Seville between 1618 and 1635 . The choice of this city is justified by the fact that one of the most prolific print shops in Spain, with respect to the production of news pamphlets, was located in the Andalusian capital, ${ }^{3}$ which led the field in the second half of the sixteenth century and came second only to Barcelona in the first half of the following one (Pena Sueiro and Fernández Travieso, 2013). The corpus encompasses the period from the years running up to the outbreak of the Thirty Years War until the start of the armed conflict with France, a moment of remarkable vibrancy and interest in the history of journalism in the early modern age. If the former served to boost the demand for news on the part of the citizenry of all the Western European states, ${ }^{4}$ the latter signified for Spain the beginning of a period of relative isolation with respect to news networks, owing to the blockade that prevented the Spanish postal routes crossing French territory from being used (Díaz-Noci, 2012).

Thanks to the information retrieved from different databases, we compiled 162 digitised news pamphlets, ${ }^{5}$ published in Seville between 1618 and 1635, comprising the corpus of our research. ${ }^{6}$ Its broad scope enabled us to obtain statistics on the proportion of illustrated news pamphlets, as well as percentages relating to those classified according to the type illustration that they contain. Thus, on the basis of a local and chronologically segmented analysis, we have been able to arrive at a number of conclusions about the importance and function of illustrations in relation to the front-page design of the first journalistic formats in history, which can be contrasted in future studies employing different corpora. Following this, we analysed those illustrations that, by our reckoning, are especially symptomatic of production aspects on which scant research has been conducted to date, such as those pertaining to the provenance of the sources and the funding of news pamphlets. This qualitative approach has allowed us to offer new interpretations of aspects including news ownership in the printing trade and the propaganda strategies guiding its production in the Early Modern age.

\section{FRONT-PAGE ILLUSTRATIONS IN NEWS PAM- PHLETS}

The first important finding of our research has to do with the proportion of news pamphlets with front-page 
illustrations. Research on journalism in the Early Modern age has defined the first formats-news pamphlets, ballads and other broadsheets with an informational purpose-as publishing genres in which the combination of images and typographical resources is central to understanding their success and popularity (Chartier, 1994). This is a subjective observation, based on the experience of the researcher in digital archives and libraries, for to the best of our knowledge the presence of illustrations in the first news pamphlets has yet to be quantified. In our corpus of Spanish news pamphlets published between 1618 and 1635 and available in digital format, the proportion is roughly 66 per cent. Namely, a third of them lack frontpage illustrations. Accordingly, the historiographical cliché that holds that the image was an indispensable element of these popular press formats in the Early Modern age should be-at least—qualified, for the absence of this eye-catching element did little to diminish their popularity, even in a city with low literacy rate like Seville.

The news pamphlets without any front-page illustrations in our corpus are plentiful enough to allow us to inquire into the reasons why their printers or sponsors chose this option. Barring a few exceptions, their analysis does not allow us to identify a clear criterion as to why they were dispensed with. The most evident exceptions include those in which the length of the text probably obliged the printer to reduce the paratextual elements to a minimum. An illustrative example of this is Carta nuevamente enviada a los padres de la Compañía de Jesús... [A new letter sent to the fathers of the Company of Jesus...], printed by Juan de Cabrera in 1625, offering an account of the martyrdom of missionaries in Japan. ${ }^{7}$ One of its lines, following the title and in italics, reads as follows: "Por ser mucha la materia que aquí no cabe, se queda imprimiendo la segunda parte" [Since there is much material for which there is no room here, a second part will be printed]. Indeed, the text filling its four pages is in a smaller font than usual and there is practically no spacing between the paragraphs.

Particularly brief and irrelevant from a graphic point of view are the titles of the news pamphlets containing the famous letters of Andrés de Almansa y Mendoza, ${ }^{8}$ such as Tercera carta que escribió un caballero de esta corte a un su amigo [A third letter that a gentleman of this court wrote to his friend], which was published without an imprint-although probably in Seville_in $1621 .^{9}$ This begs the question of whether or not the absence of illustrations was simply a prudent decision to avoid censorship. As a matter of fact, the only illustration featuring in another of Almansa's letters, entitled, Relación verdadera y general de todo lo sucedido en la Corte... [A true and general account of everything that has occurred at the court...] and printed by Serrano de Vargas in the same year, ${ }^{10}$ is a small crown, which under no circumstances intended to associate it with the official coats of arms of the monarchy; a point that will be discussed further on.

At any rate, barring these exceptions, the reasons why news pamphlets belonging to thematic series-such as naval battles, for example-did not include any front- page illustration alluding to the topic in question when this was a matter of course, will be revealed further on. Nonetheless, two editorial criteria can be gleaned from the analysis of our corpus, which could be confirmed by studying more extensive corpora:

a) The absence of front-page illustrations is more frequent in religious news pamphlets: in some cases, a small allegorical image is included, such as the head portrait of a saint or the coat of arms of some or other religious institution, but there are no illustrations whatsoever in the vast majority of them.

b) The absence of front-page illustrations is also more commonplace in informational news pamphlets recounting extraordinary events, like natural catastrophes, moral outrages or miracles. This observation confirms that the sensationalism of a part of the journalistic production in the Early Modern age-otherwise very thin on the ground in our corpus-was basically reflected in the titles. ${ }^{11}$ Only two of the news pamphlets that we have analysed feature images relating to the extraordinary events that they narrate: a crude woodcut occupying the entire front-page, depicting two crosses discovered in the trunk of an orange tree, in the news pamphlet entitled, Dos romances en que se da cuenta del maravilloso prodigio destas santas cruces... [Two ballads in which an account is offered of the wonderful prodigy of these holy crosses...], printed by Serrano de Vargas in $1620 ;{ }^{12}$ and the "monster" portrayed in a broadsheet - the only one in our corpuspublished by Juan de Cabrera in 1624, under the title, Prodigioso suceso que en Ostraviza tierra del Turco ha sucedido... [Prodigious event that has occurred in Ostraviza, land of the Turk...]. ${ }^{13}$

Of the approximately 66 per cent of the Spanish informational news pamphlets with front-page illustrations, a little less than a third contain one relating to the news recounted in them. In other words, these images were not produced for specific news pamphlets (except in the case of the two aforementioned publications covering extraordinary or miraculous events). The front-page of a ballad, recounting the wondrous case of a woman who bore 52 children in 12 years, features a-very rough and wornwoodcut depicting a building and two human figures, in all likelihood reused time and again, for its connection to the news is barely perceptible.

In the main, the images illustrating the news pamphlets deriving from materials that had already been used and were thus readily available in print shops, were practically always employed to identify visually the type of content that they contained and the subgenre to which they belonged: like the chalice adorning some of the news pamphlets covering religious issues or-and much more interesting from the perspective of the history of journalism-the illustrations depicting naval battles, which were generally used to associate the product with the military news pamphlet subgenre. The latter was widely resorted to by the Spanish printers figuring in our corpus, thus evincing an incipient professional awareness which prompted them to attempt to ensure that their news pamphlets could be visually identified to a certain extent. Five of these 


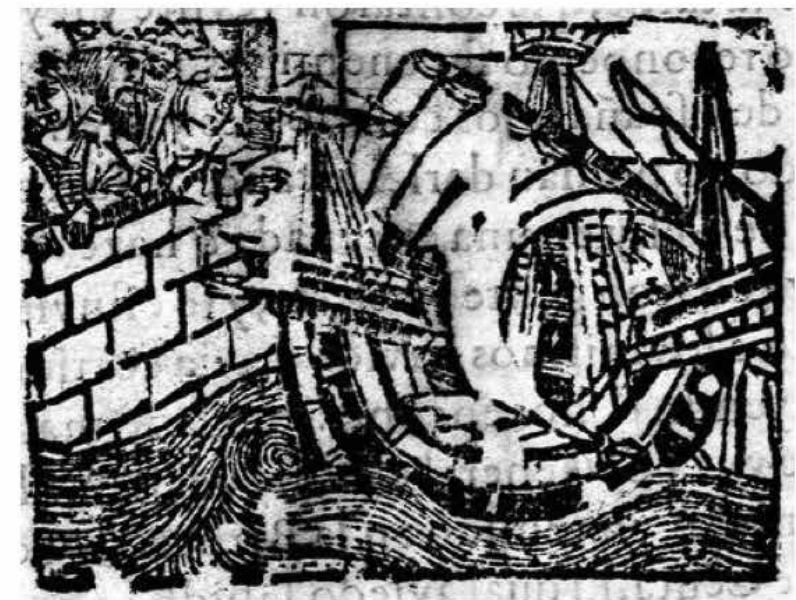

Juan Serrano de Vargas / Juan de Cabrera

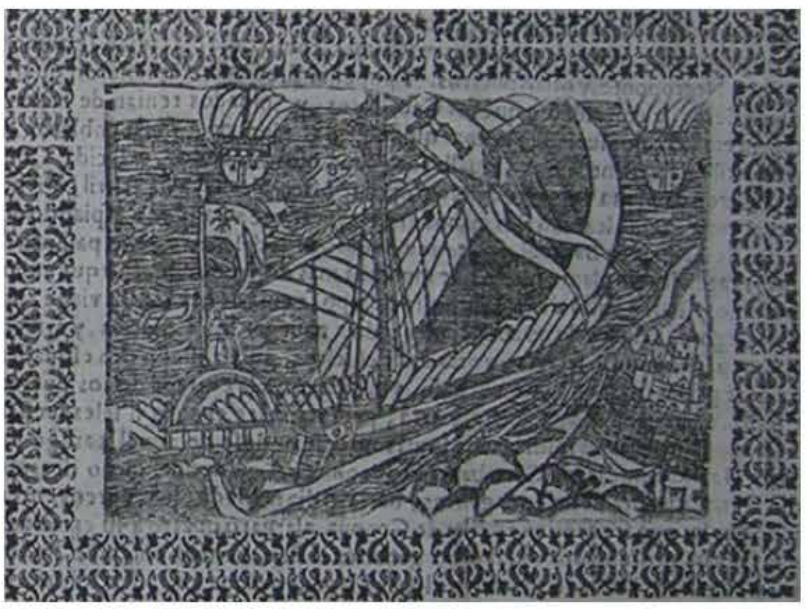

Juan de Escobar

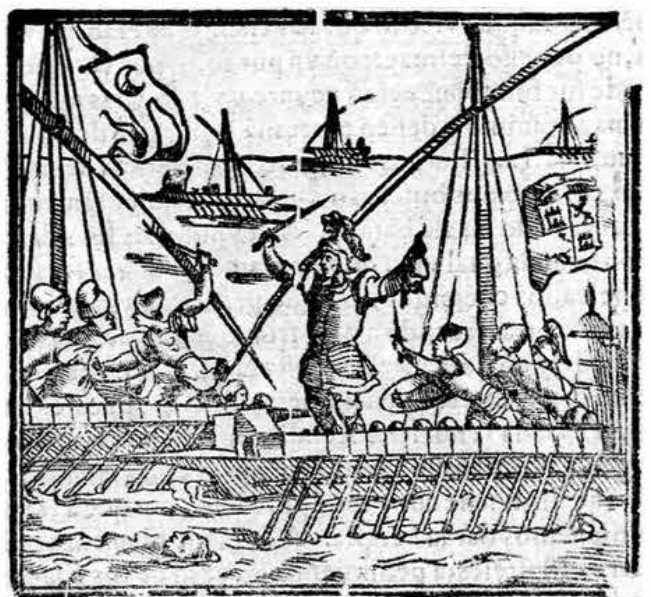

Viuda de Clemente Hidalgo

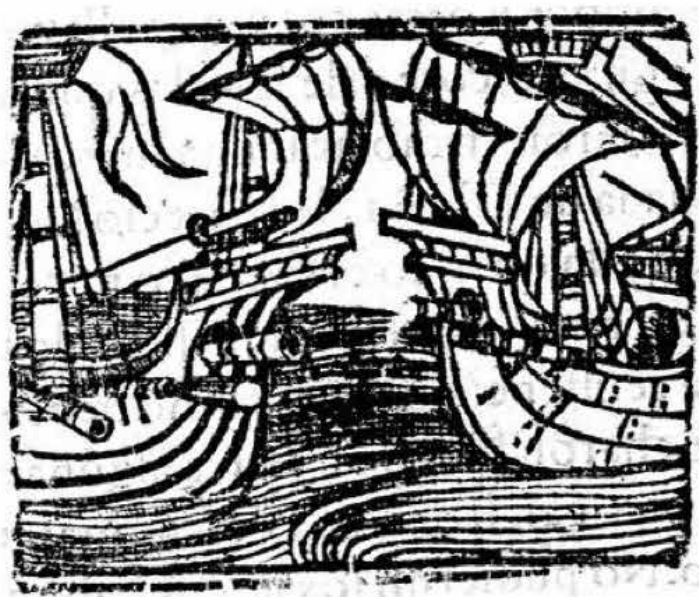

Francisco de Lyra

FIGURE 1. Different front-page engravings that Spanish printers included in their news pamphlets to illustrate accounts of naval battles. Source: Fondo Antiguo de la Universidad de Sevilla, Catálogo y Biblioteca Digital de Relaciones de Sucesos (CBDRS).

printers-Juan Serrano de Vargas, Viuda de Clemente Hidalgo, Juan de Escobar, Francisco de Lyra and Juan de Cabrera (Fig. 1) - possessed their own illustration depicting a naval battle, which they included in one or more of their news pamphlets as a way of identifying their content or the subgenre to which they belonged. ${ }^{14}$

Juan de Cabrera was the first Spanish printer who seems to have been more aware of the value of graphic and paratextual resources in the layout of news pamphlets (Espejo-Cala and Baena-Sánchez, 2016). In addition to the engraving with the naval motif, which was used to illustrate news pamphlets narrating the endless clashes between armadas in the northern seas and the Mediterranean, he included two small and elegant woodcuts representing armed riders, one holding a standard, in four news pamphlets: one of the two riders appears in two of them and both in the other two (Fig. 2). In all likelihood, these engravings served to make a series of news pam- phlets, dedicated to recounting land battles involving the Habsburg armies, recognisable to the public at large. Another three news pamphlets, two of which were printed in 1626 and the other in 1629, feature large medallions bearing the head portrait of a classical warrior-in 1626 and 1629 - and that of a lady — in 1626 — as before probably indicating the existence of a series dedicated to recounting the feats of arms of eminent political personages of the period: the Emperor of Germany in those news pamphlets featuring the warrior, and the Infanta Doña Isabel of Flanders in the one featuring the lady (Fig. 2).

During the first three decades of the seventeenth century, Spanish printers thus used front-page engravings for their editorial value, as paratextual elements that identified news pamphlets as belonging to the same series covering military, political or court news. With their introduction, journalistic design took its first tentative steps in an evolution that would ultimately distance news pamphlets 

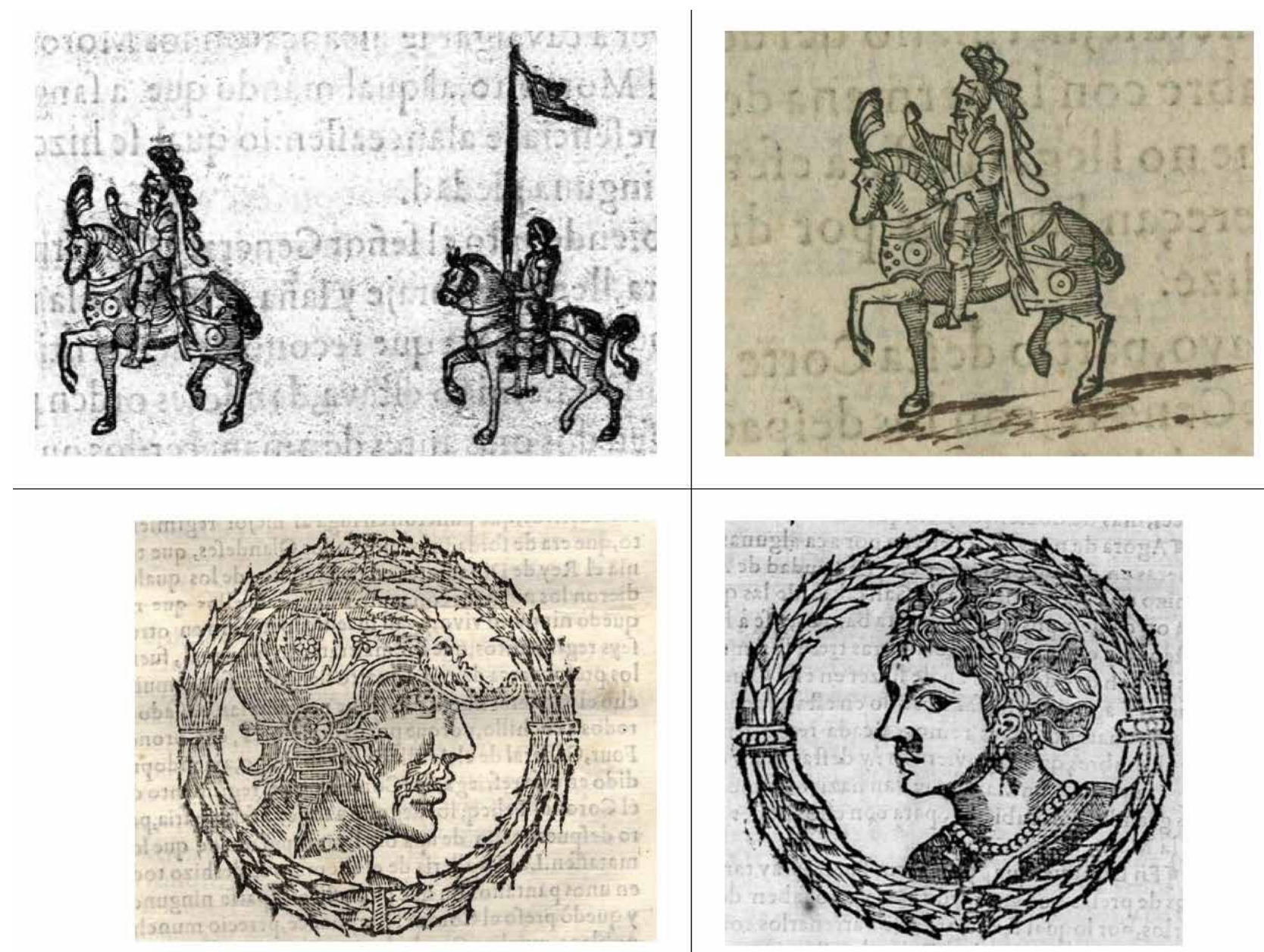

FIgURE 2. Engravings employed by the printer Juan de Cabrera in a series of news pamphlets dealing with land battles and feats of arms. Source: Fondo Antiguo de la Universidad de Sevilla, Catálogo y Biblioteca Digital de Relaciones de Sucesos (CBDRS).

from the rest of the broadsheets, creating their own market with high expectations for commercial success.

\section{THE COAT OF ARMS IN THE FRONT-PAGE OF NEWS PAMPHLETS}

Nearly 70 per cent of the news pamphlets with frontpage illustrations feature a coat of arms or escutcheon. In absolute terms, the front-pages of 46 per cent of the news pamphlets in our corpus include a coat of arms, thus enabling us to claim that printers resorted to this type of image most often to make the novel format on sale recognisable to their readerships. ${ }^{15}$

Equally significant is the fact that 70 per cent of the escutcheons featuring in the news pamphlets making up our corpus correspond to the coats of arms of the king of Spain (i.e. royal coats of arms). As occurred in the case of the engravings depicting naval battles, the royal coats of arms formed part of the resources readily available to printers. Two of these appear in the news pamphlets in our corpus: the first—employed by the Spanish monarchs between 1580 and 1668 - coincides with the standard of the House of Habsburg, quartered with the escutcheons of the many territories over which it held sway and stamped with the royal crown (Fig. 3); the second is the coat of arms of Charles I, supported by the two-headed eagle that sometimes includes the motto Plus Ultra (Fig. 4). These two coats of arms were apparently used indistinctly to refer to the same monarchical state. We have identified at least 13 different designs: five are versions of the coat of arms of Charles I and the other eight are adaptations of that of the Habsburgs. The most frequently employed version, in which the coat of arms is surrounded by a thick golden fleece, appears in 11 different news pamphlets, published by printers like Serrano de Vargas, Juan de Cabrera and Simón Fajardo between 1619 and 1626.

In the case of some printers including Gabriel Ramos Bejarano, Andrés Grande and María Pérez, only the use of a royal coat of arms, always that of the House of Habsburg has been documented. But other prominent printers plying their trade during those decades had a woodcut of each one of the two abovementioned coats of arms, and some even possessed different versions of the same one. Francisco de Lyra, for instance, used the coat of arms of Charles I in a news pamphlet published in 1618, but in 


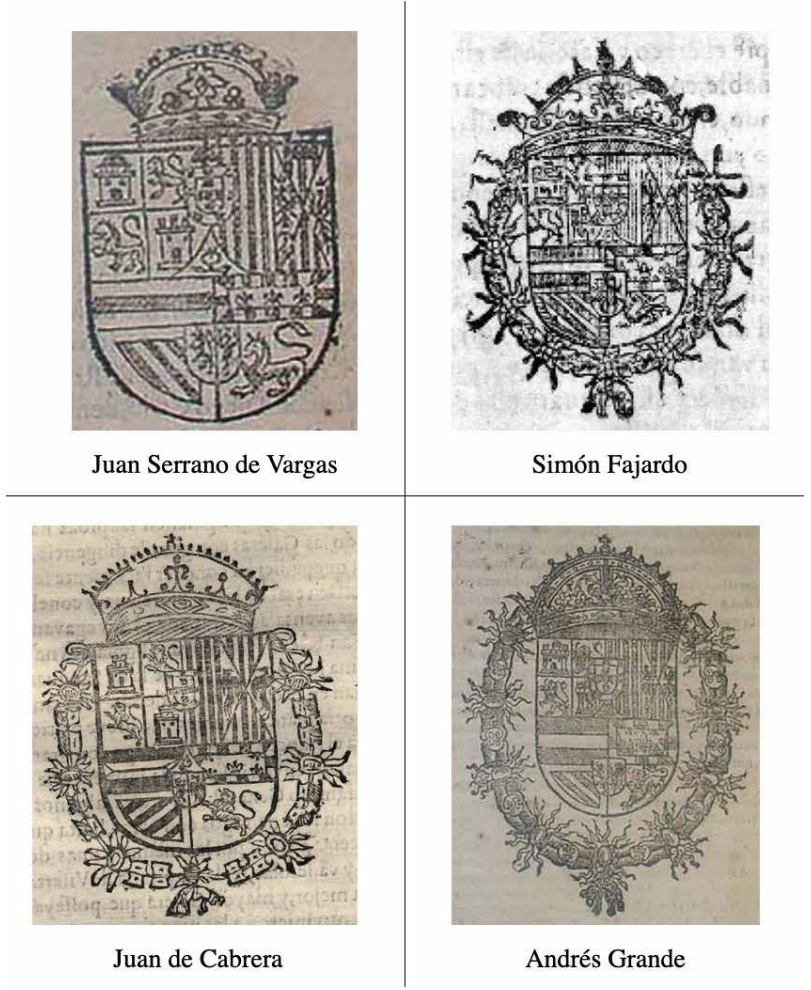

Figure 3. Different versions of the coat of arms of the House of Habsburg employed by Spanish printers as front-page illustrations. Source: Fondo Antiguo de la Universidad de Sevilla, Catálogo y Biblioteca Digital de Relaciones de Sucesos (CBDRS).

several subsequent ones-up until 1623-he employed a new, somewhat more stylised version of it. In contrast, Serrano de Vargas used a coat of arms of the House of Habsburg between 1619 and 1622, while employing a simpler and cruder version of the same escutcheon in 1624. Although the exchange of materials between printers cannot be ruled out, we believe that the use of the same coat of arms by different printers is down to the fact that engravers drew inspiration from common models, viz. those used by the Crown in its administration.

At the time, therefore, the news was made available to the reading public through an editorial format that suggested an official character. This did not necessarily emanate from the subject broached in the news-however much of the news pamphlets speak of the monarch and the deeds of his armies-but from the proximity of the information sources to Court circles (Soto-Escobar and Espejo-Cala, 2019). Thus, for example, the front-page of Relación verdadera de la muerte del Gran Turco Acomates y de los bandos, y discordias sobre la sucesión de aquel Imperio, juntamente con las razones, y causas de su muerte... [True account of the death of the Great Turk and the factions and strife arising from the succession of that Empire, together with other reasons, and the causes of his death... $],{ }^{16}$ a Seville edition printed by Francisco de Lyra in 1618 , features a coat of arms with a large two-headed eagle. The account deals exclusively with current news

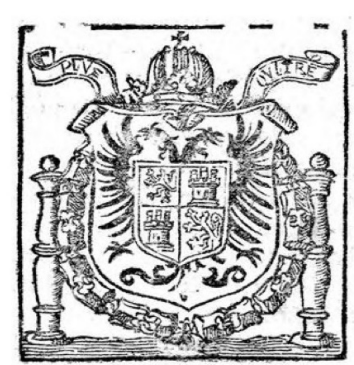

Francisco de Lyra

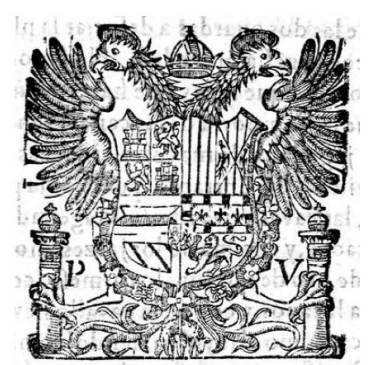

Juan de Cabrera

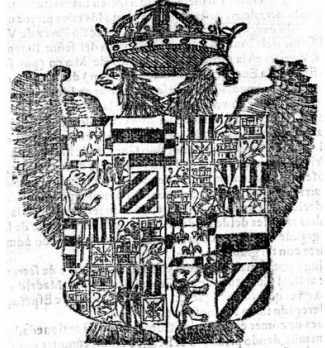

Juan Serrano de Vargas

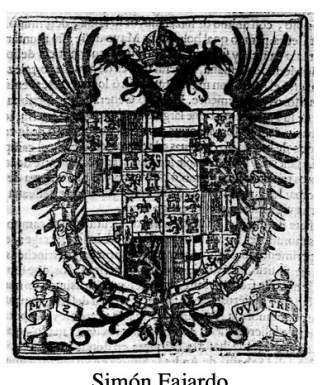

FIGURE 4. Different versions of the coat of arms of Charles I employed by Spanish printers as front-page illustrations. Source: Fondo Antiguo de la Universidad de Sevilla, Catálogo y Biblioteca Digital de Relaciones de Sucesos (CBDRS).

from the Ottoman Empire, but the coat of arms and some or other allusion to "our lord" the king suggest the official status of the sources and the Hispanic point of view from which the news is being told.

Versus the overwhelming presence of the official coat of arms of the Crown, the escutcheons of other political institutions appear in four news pamphlets: that of the annexed kingdom of Portugal in the news pamphlet produced by Serrano de Vargas, offering an account of Philip III's trip to Lisbon in 1619, and that of the city of Seville in the other three. The latter features in a news pamphlet, also printed by Serrano de Vargas in 1619, describing a political ceremony held in Seville, Relación del día, acompañamiento, forma, y ceremonias como se levantó el Pendón real... [An account of the day, accompaniment, form and ceremonies, and how the royal banner was hoisted] $]^{17}$, which contains a text signed by the scribe of the Chapter. In this case, the coat of arms refers to both the local nature of the news and the official character of the edition, sponsored and promoted by the local authorities of Seville. On the contrary, two news pamphlets printed by Juan de Cabrera in 1626 contain court news from Madrid or from the warfronts of the Spanish monarchy, without there being any clear link to the Andalusian capital. One of these contains a text practically identical to that of another news pamphlet published by the same printer in the same year, except that the order in which the news is given differs in each case. The front-page of the first-Paces entre España, Francia, y otros potentados... [Peace between Spain, France and other powers $]^{18}$ - displays the coat of arms of the city of Seville, while that of that second-Relación verdadera entre España, y Francia, y otros poten- 
tados... [The true relationship between Spain, France and other powers $]^{19}$ - bears the royal coat of arms of Charles I. Owing to the fact that printers gained the favour of the authorities by printing special editions for them, distributed before those destined for the general market, it seems reasonable to assume that these curious, duplicated news pamphlets were produced because the Chapter or some other Seville institution had defrayed the cost of an edition for its own internal consumption (González Fandos, 2018). This enigmatic double edition therefore shows that the coats of arms figuring on the front-pages refers to both the information channels and sources-in this case, the news pamphlets bearing the royal coat of arms - and their sponsors-in this case, the coats of arms of other powers of the modern state.

The front-pages of a small number of news pamphlets-only six in our corpus-are emblazoned with ecclesiastical coats of arms. On occasion, this escutcheon was also included in reference to the narrated news, as in the case of the coat of arms of a religious order featuring on the front-page of a news pamphlet printed by Juan Serrano de Vargas in 1620, offering an account of the achievements of a Mercedarian friar in the redemption of captives in North Africa, under the title Tres maravillosos casos que le sucedieron al Padre Maestro Fr. Juan de Santiago... [The wondrous things that happened to Father Juan de Santiago....]. ${ }^{20}$ The same can be said of the coat of arms of the Inquisition preceding the account of an autoda-fe, printed by Juan de Cabrera in 1627, under the title Relación del auto de fe que celebró en Santo Oficio de la Inquisición en Sevilla... [An account of the auto-da-fe held at the Holy Office of the Inquisition in Seville...]. ${ }^{21}$ In some or other case, the coat of arms alludes to the recipients or main characters of the dedication, as in two news pamphlets in our corpus: one published by Gabriel Ramos Bejarano in 1619 and the other by Juan de Cabrera in 1630. The former-Breve relación de la presente persecución de Irlanda... [A brief account of the current persecution in Ireland.... $]^{22}$-addressing the religious conflict in England, is dedicated to the archdeacon of Seville Félix de Guzmán and uses his coat of arms as a front-page illustration. Similarly, the front-page of the latter-Relación de la gracia y merced... [An account of grace and mercy... $]^{23}$-narrating, among other political news, how Diego de Guzmán Patriarch of the Indies and archbishop of Seville had been created a cardinal, is emblazoned with this Prince of the Church's coat of arms.

Gazeta romana y relación general de avisos... [Roman gazette and general news...], ${ }^{24}$ published by Juan Serrano de Vargas in 1618 - one of the clearest and earliest examples of how the gazette format was adapted to the Spanish market-which contains news about European international politics (Ettinghausen, 2012), features the coat of arms of Pope Paul V as a front-page illustration. The Pontiff and his curia are the focus of several news pieces, but what justified the use of the coat of arms is not this thematic reference, but the fact that the gazette was composed and "enviada por un curioso caballero sevillano, que asiste en Roma, a otro, también curioso, que asiste en la ciudad de Sevilla" [sent by an curious Seville gentleman currently in Rome, to another also curious gentleman in the city of Seville], according to its title. In other words, it is yet again the origin of the source that is visualised through the graphic element, with the intention of giving the product an official air. Albeit less well known, there is another news pamphlet printed by Serrano de Vargas - in 1621 - with the same papal coat of arms as a front-page illustration, except, in this case, without the floral adornment that occupies the empty escutcheon in the previous news pamphlet. It is probably the continuation of this serial gazette, of which only these two numbers have come down to us; its title is as follows: Relación de avisos de Roma, Flandes, Sicilia, Alemania, Francia, Florencia, y Argel... [An account of developments in Rome, Flanders, Sicily, Germany, France, Florence and Algiers... $].{ }^{25}$

The front-pages of eight news pamphlets are emblazoned with noble coats of arms-differing from those of the royal house. The coat of arms of the Ducal House of Medina Sidonia appears in two news pamphlets in our corpus, printed by Juan de Cabrera and Francisco de Lyra, respectively, in 1624: the first-Bosque de Doña Ana... [Forest of Doña Ana... $]^{26}$ —refers to the celebrated reception that the 8th Duke offered Philip IV in his Andalusian possessions, while the second-Presa que el señor don Francisco de Guzmán y Zúñiga... [A prize that His Grace Don Francisco de Guzmán y Zúñiga.... $]^{27}$ —deals with the military exploits of his cousin, the Marquis of Ayamonte. In both cases, the coat of arms is elegantly depicted and occupies most of the front-page: the knowledge that we have of the promotion strategies of the Ducal House of Medina Sidonia during this period enables us to deduce that these editions were also sponsored by those featuring in them. ${ }^{28}$ The coat of arms of the 3rd Duke of Alcalá de los Gazules, Don Fernando Enríquez Afán de Ribera, appears in Relación de la alegre entrada en público que hizo en Roma... [An account of the joyful public entrance that he made in Rome...], ${ }^{29}$ a news pamphlet printed by Simón Fajardo in 1625, offering an account of the aristocrat's arrival in Rome as the extraordinary ambassador of Philip IV. His family, one of the Andalusian capital's most illustrious, was probably behind this edition.

In other cases, however, the reason why a particular coat of arms was chosen is not so clear. The printer Juan de Cabrera published five enigmatic news pamphlets whose front-pages bear other noble coats of arms: two of these, printed in 1626 and 1628, include engravings depicting the coat of arms of the well-known Juan Antonio de Vera y Figueroa, Count de la Roca since $1628^{30}$ : Verísima relación en que se da cuenta en el estado en el que están los católicos de Inglaterra... [Very truthful account describing the situation of the Catholics in England.... $]^{31}$ and Feliz victoria que ha tenido el cristianísimo Rey de Francia, sobre el cerco de la gran ciudad de la Rochela... [The fortunate victory that the very Christian king of France has obtained in the siege of the great city of La Rochelle... $]^{32}$ (Fig. 5).

This aristocrat from Extremadura formed part of the circle of friends of Gaspar de Guzmán, the future Count- 


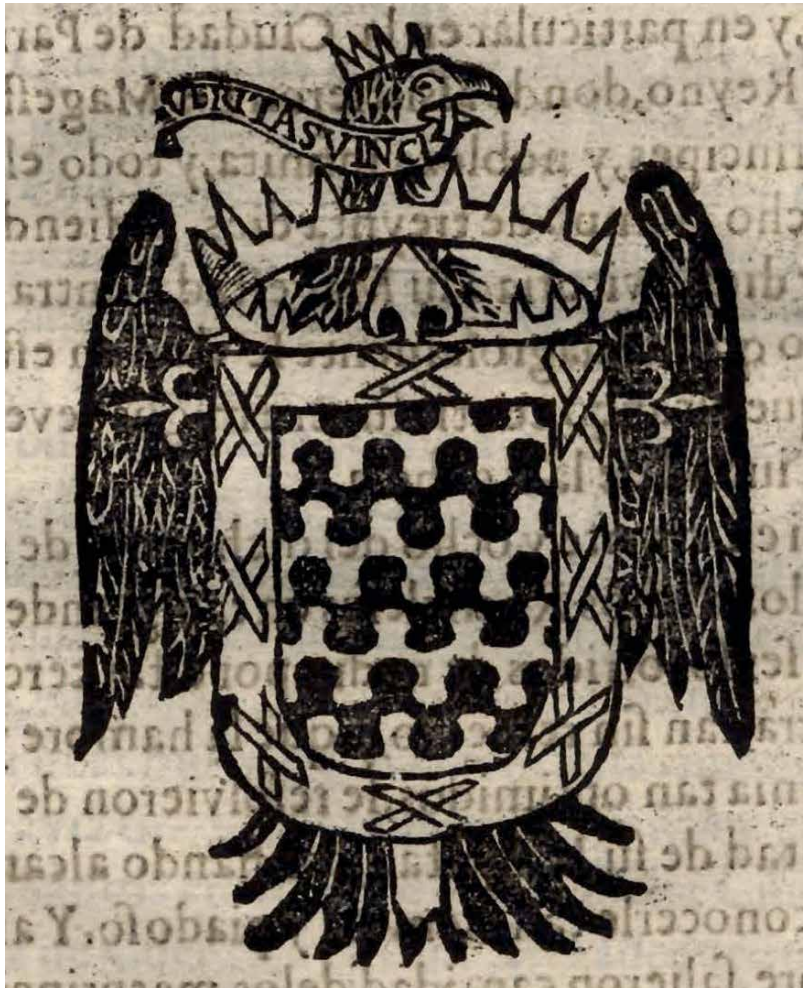

FIGURE 5. The coat of arms of the Count de la Roca included by the printer Juan de Cabrera in two news pamphlets published in 1626 and 1628, respectively. Source: Catálogo y Biblioteca Digital de Relaciones de Sucesos (CBDRS).

Duke of Olivares, the very influential favourite of Philip IV, both of whom resided in Seville. ${ }^{33} \mathrm{He}$ served as a diplomat of the Spanish Crown in Savoy between 1625 and 1626 , as well as undertaking other subsequent missions in Italy, but his international fame rested chiefly on the publication of his book El embaxador in 1620, which was translated into French and Italian shortly afterwards. It is a treatise on diplomacy that includes details on how to write avvisi or news; the sources of the period claim that Richelieu feared the Count de la Roca's ability to learn about new developments and to inform his king about them before any other ambassador (Soto-Escobar, 2019).

The two Seville news pamphlets bearing the coat of arms of the Count de la Roca contain diverse international news, above all about the conflicts between Catholics and Protestants in England and France, as announced in their titles. Given the diplomat's position, we can speculate that the news reached the Seville printing shop via the communication channels use by the Count de la Roca, who promoted or, at least, permitted its public dissemination, plus the use of his coat of arms-associated with the editorial product as a selling point and guarantee of veracity.

The other three news pamphlets, two of which were published in 1625 and the other in 1629, include the coat of arms of a noble family that we have not been able to identify, although the three black water-cress leaves associating it with that of the Vera y Aragón family, to which the Count de la Roca belonged, appear in one of its quar- ters (Fig. 5). From a reading of the news pamphlets published in 1625-Famosa relación en que se avisa de cómo en una grande refriega... [Famous account that narrates how in a major skirmish... $]^{34}$ and Retirada del Duque de Saboya... [Retreat of the Duke of Savoy...] ${ }^{35}$ —it can be inferred that it was destined for someone living in Seville, who was keen to keep abreast of the news from Italy, particularly from Genova, although unquestionably the ultimate intention was its public dissemination through the printed word. The third news pamphlet-Grandiosa relación de la famosa mascara... [An admirable account of the masked ball... $]^{36}$ —describes the masked ball that the Duke of Medina de las Torres, the son-in-law of the Count-Duke of Olivares, organised in honour of Prince Balthazar, the heir to the throne. It does seem to have been sent to anyone in particular, although several gentlemen of Genovese provenance or professionally linked to Genova are mentioned among those attending the court soirée: Juanetín (Giannettino) Doria, the son of the Duque of Tursis; Vicente Espínola and, once again, the Count de la Roca. All considered, it can perhaps be concluded that these news pamphlets were sponsored by members of the prosperous community of Genovese traders established in Seville since the fifteenth century, ${ }^{37}$ who in the first decades of the seventeenth century sought ennoblement and even higher dignities. ${ }^{38}$

Therefore, and notwithstanding their exceptional character in our corpus, the inclusion of ecclesiastical or noble coats of arms on the front-pages of serial news pamphlets and gazettes in the first decades of the seventeenth century is a significant indication of the local communication structure in which these works were produced. A more comprehensive study of more extensive corpora, combining text and iconographic analyses with archival documents, would allow us to identify who was interested in disseminating certain news, to the point of 'filtering' the information that they had received privately or defraying the cost of its publication. We would then be in a position to gauge the importance of patronage in the production of the first journalism in European history-an aspect without which any description of the communication structure of the period would be incomplete-and to identify who were the owners of the news in Spain during the Early Modern age.

\section{CONCLUSSIONS}

The study of the front-page illustrations of news pamphlets published in Seville between 1618 and 1635 has enabled us to arrive at a number of telling conclusions as regards their editorial role. First and foremost, the fact that approximately a third of the news pamphlets in our corpus do not include them contradicts a bibliographical truism, for they were meant to attract the attention of the illiterate public and help them to contextualise and understand the information. Printers, in contrast, decided against including illustrations in their news pamphlets for editorial reasons: when the text was so long as to occupy all the available space; when it was prudent not to associ- 
ate a delicate issue with an image that might be misinterpreted; or maybe simply when it was urgent to publish the news or when there was no suitable image available. The thematic subgenres in which the incorporation of an illustration was most often ruled out include religious news pamphlets and those dealing with extraordinary or scandalous events. The latter indicates that the sensationalism of these first European news products was mostly apparent in their text resources such as titles and headings.

From the analysis of the approximately 66 per cent of the news pamphlets in our corpus that do include frontpage illustrations, we have been able to draw three main conclusions:

a) In practically all of these news pamphlets, the illustrations featuring in them are unrelated to their subject matter. In contrast, in a third of them they are indeed related to the theme of the news, thus helping readers to identify the series to which they belonged: the series on naval battles in the northern seas or the Mediterranean; the series on major military conflicts in Central Europe; or the series on the political actions of important personages of the period. Therefore, they are stereotyped illustrations that were included by different printers in several news pamphlets associated with series such as those mentioned above. To give just one example, nearly all of the Seville printers plying their trade during this period possessed an engraving depicting a naval battle, which they used to illustrate news pamphlets covering such developments. To our mind, this demonstrates the emergence of a journalistic awareness among printers-who were already playing the role of news editors to certain extent-for the progressive standardisation of front-page designs would inevitably lead to the appearance of the newspaper header decades later.

b) In absolute terms, coats of arms appear most frequently - in two thirds of the news pamphlets with front-page illustrations and in half of those in our corpus. In turn, the most commonplace coat of arms is that of the royal house, either that of Philip IV of the House of Habsburg or the imperial coat of arms of Charles I. The Seville printers had access to engravings depicting these coats of arms - in one or more versions - which they included consistently in their news pamphlets to underscore the authority of their information sources. This has allowed us to identify the growing officialization of Spanish journalism in the Early Modern age, even predating the advent of the first gazette directly backed by the Crown: the Gazeta Nueva in 1661.

c) The front-pages of a small proportion of the serial news pamphlets or gazettes are emblazoned with other coats of arms, either those of prominent churchmen or aristocrats. In our view, they are especially interesting, for they apparently demonstrate the links between the news market and the local powers that be. For instance, the coats of arms of powerful families, such as the Dukes of Alcalá and, primarily, the Dukes of Medina Sidonia, appear on the front-pages of some of the news pamphlets in our corpus. This is also the case with the coat of arms of the Count de la Roca, a well-known Seville diplomat and writer, whose main occupation seems to have been that of spy/informer for the political authorities. The presence of his coat of arms in several news pamphlets suggests that he promoted the public dissemination of some of the news to which he had access, all of which makes it essential to perform an in-depth study on this fascinating historical character. Lastly, the coat of arms of a family that we have not been able to identify seems to link the production of news pamphlets to the important Genovese colony in Seville, which is yet another aspect that should be examined more closely.

In sum, research on the front-page illustrations of news pamphlets published in the Early Modern age is essential for gaining a deeper understanding of an editorial product in which the first notions of journalistic design appeared. Furthermore, when the illustration in question is a coat of arms, it can be employed to inquire into elements of the communication structure-for instance, relationships of patronage or clientelism between printers and local potentates-which go undetected in a merely bibliographic or text analysis. This study has helped us to gain further insights into the news market, determining who were the powers - state or local, ecclesiastical or aristocratic, macro or micro - with a vested interest in the circulation of the first media products in Europe.

\section{ACKNOWLEDGMENTS}

This work was supported by the projects: Biblioteca Digital Siglo de Oro 5 (BIDISO 5), FFI201565779-P, Ministerio de Economía y Competitividad del Gobierno de España and Fondo Europeo de Desarrollo Regional (FEDER); and Historia Crítica del Periodismo Andaluz (HICPAN), P18-RT-1552, Ayudas a la I+D+i del Plan Andaluz de Investigación, desarrollo e innovación (PAIDI 2020) de la Consejería de Economía y Conocimiento de la Junta de Andalucía (1-01-2020/ hasta el 31-12-2022).

\section{NOTES}

1 A number of important works - both bibliographic and structural - on the title-pages of books printed in the Early Modern age have seen the light of day. See Judson (1978); Smith (2001). For a work specifically dealing with printing in Spain, see Reyes Gómez (2010).

2 For a comparative analysis of Spanish printing in Western Europe in the early modern age, see Wilkinson and Ulla (2017).

3 In order to understand the importance of the Seville print shops in the Spanish and European contexts, see Domínguez (1992); Álvarez, (2007); Castillejo (2019); Peñalver (2019).

4 Over the past few decades, the proliferation of databases with digital repositories and the collaboration between researchers of different nationalities have both favoured an exponential increase the knowledge on the birth of journalism in Europe. Some works offering a global overview, from a pan-European perspective and published in different languages, are: Infelise (2001); Dooley and Baron (2001); Haffemayer (2004); Welke and Wilke (2007); Chartier and Espejo (2012); Sousa (2013); Pettegree (2014); Ettinghausen (2015) and Raymond and Moxham (2016).

5 The Universal Short Title Catalogue (USTC) database (https:// ustc.ac.uk/> [accessed 26 December 2019]) enabled us to retrieve a total of 482 news pamphlets published in Seville between 1618 
and 1635 , which can be classified in the news book genre and of which 123 are currently available in digital format. Despite the important task of compiling news pamphlets undertaken by this international database, it has yet to include all the Spanish bibliographic collections of news pamphlets published in the Early Modern age. It is still essential to consult the Catálogo y Biblioteca Digital de Relaciones de Sucesos (<https://www.bidiso.es/ CBDRS/> [accessed 26 December 2019]), among other databases including the virtual exhibition Relaciones de Sucesos en la Bus. Antes de que existiera la prensa ... (<https://expobus.us.es/s/Relaciones-de-Sucesos-en-la-BUS/page/inicio> [accessed 24 December 2019]).

6 Space constraints make it impossible here to offer a full list of the news pamphlets making up the corpus. We have decided, instead, to cite their abbreviated titles and to modernise the spelling of their copy, as well as including bibliographic references in the footnotes, as they appear indexed in the USTC.

7 Carta nuevamente embiada a los padres de la Compañia de Jesus, en que da quenta de los grandes martirios que en el Japon, an padecido muchos padres de muchas religiones (Sevilla, Juan de Cabrera, 1625) USTC 5008390.

8 Almansa is the first Spanish journalist known by name; a preliminary study can be found in Almansa y Mendoza (2001).

9 Andrés de Almansa y Mendoza, Tercera carta que escrivio una cavallero desta corte a un su amigo

(S.1. [=Spain?], unnumbered, [1621]) USTC 5004418.

10 Andrés de Almansa y Mendoza, Relación verdadera y general de todo lo sucedido en la corte, desde que murio su magestad, hasta diez y seys de mayo. En que se da quenta (entre otras muchas cosas notables) del estado de las cosas de algunos señores y los castigos y premios que el rey n.s. les ha dado, y reformacion de cosas importantes al servicio de Dios, y bien destos reynos, carta segunda que escrivio un cavallero de la corte a un su amigo (Sevilla, Juan Serrano de Vargas Urueña, 1621) USTC 5012900.

11 This observation contradicts another truism of the literature. Infantes, for instance, claims that news pamphlet illustrations are "very few and far between, except in those narrating extraordinary events, which feature woodcuts and small vignettes that visually describe the case" (1996, p. 203). For a more comprehensive study of the relationship between images and sensationalism in news pamphlets in the Early Modern age, see Graham and Kilroy-Ewbank (2018).

12 The illustration's caption indicates that the engraving was originally designed for the news pamphlet, which was of course highly unusual and can solely be justified as a way of catching the attention of the local public, for it recounts events occurring in a town close to Seville: "Adviértase, que estas cruces se copiaron por las verdaderas, y no se pintan, por ni les dar colores impropios, así al tronco del naranjo, que todos saben su color, como a las cruces, que es pardo oscuro, color semejante al de la en que Cristo murió Nótese que se declara en el romance y su longitud" [It should be observed that these crosses were copied as the true ones, and they are not painted, for nor are they given inappropriate colours, the same going for the trunk of the orange tree, which is dark brown, a colour similar to that of the cross on which Jesus died. Note that this is mentioned in the ballad, along with their length], Juan Alanis, Dos romances en que se da cuenta del maravilloso prodigio destas santas cruzes; y del que este mismo dia sucedio en la villa de Espera, diez leguas desta ciudad de Sevilla. Todo lo qual sucedio jueves dos de enero deste año de 1620 (Sevilla, Juan Serrano de Vargas, 1620) USTC 5111489.

13 Prodigioso suceso que en Ostraviza tierra de el turco a sucedido este presente año de 1624 (Sevilla, Juan de Cabrera, [1624]) USTC 5012399.

14 The woodcut employed by Juan Serrano de Vargas between 1618 and 1619 appears to be identical to the one used by Juan de Cabrera between 1624 and 1626; a typographic study would allow for ascertaining the-circumstantial or continuous-professional relationship between these two prominent Seville printers.

15 Besides the informational news pamphlets, many others include coats of arms on their front pages, such as the trial and legal reports that printing shops produced in such large numbers in the
Early Modern age; in this respect, see Ruiz (2011). On the other hand, coats of arms or escutcheons formed part of the visual culture of the Early Modern age, for they appeared on lintels, arms, furniture, fabrics and many other things; see López Poza (2008).

16 Relacion verdadera de la muerte del gran turco Acomates y de los bandos, y discordias sobre la sucession de aquel imperio, juntamente con las razones, y causa de su muerte dase cuenta de los reynos, y provincias que le ha tomado el rey de Persia, y de los embaxadores que tiene en Madrid, y de los negocios que en ella tratan (Sevilla, Francisco de Lyra, 1618) USTC 5016444.

17 Hernando de Nájera, Relacion del dia, acompañamiento, forma, y ceremonias como se levanto el Pendon real en esta ciudad de Sevilla, por el rey nuestro señor don Felipe Quarto deste nombre, que Dios guarde muchos años (Sevilla, Juan Serrano de Vargas, 1621) USTC 5030516.

18 Pazes entre España, Francia, y otros potentados, y mercedes que hizo s.m. en las cortes, en Balvastro, tierra de Aragon (Sevilla, Juan de Cabrera, 1626) USTC 5038042.

19 Relacion verdadera entre España, y Francia, y otros potentados, y mercedes que hizo su magestad en las cortes de Moncon. Y tambien se declara en el estado que estan las guerras de Flandes, y de Alemania, y otras cosas dignas de saberse (Sevilla, Juan de Cabrera, 1626) USTC 5013722.

20 Tres maravillosos casos, que sucedieron al reverendo padre maestro fr. Juan de Santiago, religioso y morador del convento de nuestra señora de la Merced desta ciudad de Sevilla, redentor de cautivos en esta redencion que hizo este presente año en los reynos de Fez, Tetuan y Marruecos (Sevilla, Juan Serrano de Vargas, 1620) USTC 5012532

21 Relacion del auto de fee que celebro el santo officio de la inquisicion de Sevilla, en el convento de San Pablo el real, que es de la orden de predicadores, segundo domingo de quaresma, que fue ultimo dia del mes de febrero, deste presente año de 1627 (Sevilla, [Juan de Cabrera?, 1627]) USTC 5004605.

22 Breve relacion de la presente persecucion de Irlanda contiene una carta embiada de Irlanda por una persona grave, y otra d'el rey de Inglaterra, con dos editos de su virrey contra los católicos (Sevilla, herederos de Gabriel Ramos Bejarano, 1619) USTC 5007248.

23 Relacion de la gracia y merced que nvestro mvy Sancto Padre y señor Vrbano Papa Octavo, a hecho al Eminentissimo señor Don Diego de Guzman Patriarcha, y Arçobispo de Sevilla, de darle el Capelo de Cardenal de la Santa Yglesia de Roma. Assi mismo se da aviso de la prospera Iornada de la Reyna de Vngria, y gran recebimiêto que en Napoles le hizo el Excelentiss. Señor Virrey, don Fernando Enriquez de Ribera, Duque de Alcala (Sevilla, Juan de Cabrera, 1630). Not registered in USTC. Digitized in Biblioteca Virtual de Andalucía, http://www.bibliotecavirtualdeandalucia. es/catalogo/es/catalogo_imagenes/grupo.cmd?path=10643\&texto busqueda $=\&$ interno $=\mathrm{S}$ [accessed 23 January 2020].

24 Gazeta romana, y relacion general de avisos de todos los reynos y provincias del mundo, embiada por un curioso cavallero Sevillano con el correo que vino lunes onze de junio de mil y seiscientos y diez y ocho años (Sevilla, Juan Serrano de Vargas, 1618) USTC 5006982.

25 Relacion de avisos de Roma, Flandes, Sicilia, Alemania, Francia Florencia y Argel muerte de su santidad Paulo Quinto, eleccion de n.s.p. y señor Gregorio Decimoquinto (Sevilla, Juan Serrano de Vargas, 1621) USTC 5009551.

26 Pedro de Espinosa, Bosque de doña Ana a la presencia de Felipo Ouarto demonstraciones que el duque VIII de Medina Sidonia, don Manuel Alonso Perez de Guzman el bueno (Sevilla, Juan de Cabrera, 1624) USTC 5011978.

27 Presa que el señor don Francisco de Guzman y Zuñiga, marques de Ayamonte hizo en veynte y cinco de junio deste presente año de 1624 en dos baxeles de turcos, moros, y renegados que corrian aquella costa, y hazian daño en la gente de mar del dicho lugar y comarcanos (Sevilla, Francisco de Lyra, 1624) USTC 5026333.

28 The communication strategy of the Ducal House of Medina Sidonia, the most powerful in the south of the Iberian Peninsula, has been studied by Salas (2013) and Espejo-Cala (2019).

29 Relacion de la alegre entrada en publico, que hizo en Roma el excelente señor don Fernando Enriquez Afan de Ribera, duque 
de Alcala A Veynte y siete de julio deste año de mil seyscientos y veynte y cinco (Sevilla, Simón Fajardo, 1625) USTC 5038028.

30 There is an illustration and description of the coat of arms of the Counts de la Roca on page 358 of the second part of the treatise entitled, Monarquía Española, Blasón de su Nobleza, the work of Juan Félix Francisco de Rivarola y Pineda (1736). It is available at http://www.bibliotecavirtualdeandalucia.es/catalogo/ catalogo_imagenes/grupo.cmd?path $=1000166 \&$ presentacion $=$ pagina \&posicion $=26 \&$ forma $=$ [accessed 24 January 2020].

31 Verissima relacion en que se da quenta en el estado en que estan los catolicos de Inglaterra por parte de los hereges, y con el zelo que la reyna los favorece. Y la grandiosa presa que las naos de Unquerque hizieron, prendiendo al duque de Buquinga, y a otros muchos cavalleros los mas principales de Londres, que avian salido a Olanda, y les quitaron todo quanto llevavan, año de 1626 (Sevilla, Juan de Cabrera, 1626) USTC 5012554.

32 Feliz victoria que a tenido el christianissimo rey de Francia, sobre el cerco de la gran ciudad de La Rochela que a tanto tiempo que la tenia cercada, y se haze assimesmo relacion del numero de navios de Inglaterra que de socoro les avia venido por mar en este año de 1628 (Sevilla, Juan de Cabrera, [1628]) USTC 5028136.

33 The Count de la Roca was the author of the first biography of the Count-Duke: Fragmentos históricos de la vida de don Gaspar de Guzmán, Conde Duque de Olivares (¿1628?).

34 Famosa relacion en que se avisa de como en una grande refriega que uvo entre la cavalleria de Milan, y Ginoveses, mataron al contrario ciento y cinquenta ombres de a cavallo y otros muchos soldados, entre los quales mataron al principe Tomas, hijo del de Saboya, y otros avisos año de 1625 (Sevilla, Juan de Cabrera, 1625) USTC 5006218.

35 Retirada del duque de Saboya a su corte de Turin, y como la cavalleria polaca de el duque de Feria, le corren la tierra hasta sus murallas, por cuyo temor, se an salido de la corte su muger $y$ hermana del principe del Piamonte año 1625. Tambien va el traslado de la carta que el rey nuestro señor embio al serenissimo Lacome Lomelin dux de Genova, dandole la norabuena de su dichosa elecion (Sevilla, Juan de Cabrera, 1625) USTC 5012506.

36 Grandiosa relacion de la famosa mascara, que a onra de el nacimiento dichoso de nuestro serenisimo principe, don Baltasar Carlos Domingo, ordeno el señor duque de Medina de las Torres (Sevilla, Juan de Cabrera, 1629) USTC 5038068.

37 The Genovese colony in Seville was first studied by Pike (1966). For another interesting contribution, see Díaz Blanco (2007).

38 On the other hand, the Vera y Aragón family, to which the Count de la Roca belonged, came from the Seville town of Estepa, which had been transferred from the old local nobility to the Genovese Centurión family-awarded the Marquisate of Estepa by Philip II in 1599 , for their financial collaboration in many of the Spanish monarchy's military adventures. This power shift was not without its problems, for the Vera y Aragón family sided with the opposition to the new oligarchs of foreign extraction. Accordingly, it is necessary to investigate the role that journalistic publications played in the communication strategy of both aristocratic camps; see Prieto (2015)

\section{REFERENCES}

Almansa y Mendoza, A. (2001) Obra periodística, Henry Ettinghausen and Manuel Borrego, eds. Madrid: Castalia.

Álvarez Márquez, M. C. (2007) La impresión y el comercio de libros en la Sevilla del Quinientos. Sevilla: Editorial Universidad de Sevilla.

Broersma, M. J., ed. (2007) Form and Style in Journalism. European Newspapers and the Representation of News 1880-2005. Leuven-Paris-Dudley MA: Peeters.

Brownless, N. (2011) The Language of Periodical News in Seventeenth-Century England. Newcastle upon Tyne: Cambridge Scholars Publishing.

Castillejo Benavente, A. and López Cipriano, L. (2019) La imprenta en Sevilla en el siglo XVI (1521-1600). Sevilla: Editorial Universidad de Sevilla.
Chartier, R. (1994) Libros, lecturas y lectores en la Edad Moderna. Madrid: Cátedra.

Chartier, R. and Espejo, C. (2012) La aparición del periodismo en Europa. Comunicación y propaganda en el Barroco. Madrid: Marcial Pons.

Conboy, M. (2004) Journalism: A Critical History. London: Sage.

Díaz Blanco, J. M. (2007) "Del "tratar noblemente" al trato de la noblez. El acceso al señorío de linajes extranjeros en Sevilla (ss. XVI-XVIII)". In: F. Andújar Castillo and J. Pablo Díaz López, coords., Los señoríos en la Andalucía Moderna. El Marquesado de los Vélez. Almería: Instituto de Estudios Almerienses, pp. 623-638.

Díaz-Noci, J. (2012) "Dissemination of News in the Spanish Baroque". Media History 18 (3-4), pp. 409-421. doi: https://doi.or g/10.1080/13688804.2012.721648

Domínguez Guzmán, A. (1992) La imprenta en Sevilla en el siglo XVII:(catálogo y análisis de su producción) 1601-1650. Sevilla: Secretariado de Publicaciones de la Universidad de Sevilla.

Dooley, B. and Baron, S. A. (2001) The Politics of Information in Early Modern Europe. London and New York: Ashgate.

Espejo-Cala, C. (2016) "The Invention of the Gazette. Design standardization in Spanish newspapers, 1600-1650". Media History 22, pp. 296-316. https://doi.org/10.1080/13688804.2016.11494 58

Espejo-Cala, C. (2019) "Andrés de Almansa y Mendoza y el círculo de los Duques de Medina Sidonia. La identidad del destinatario de las Cartas". Memoria y Civilización 22, pp. 1-21. doi: https:// doi.org/10.15581/001.22.005

Espejo-Cala, C. and Baena-Sánchez, F. (2016) "El impresor sevillano Juan de Cabrera (1623-1631): la producción de relaciones seriadas en España durante el siglo XVII'. Communication \& Society, 29 (4), pp. 203-217. doi: https://doi.org/10.15581/003. 29.4.sp.203-217

Ettinghausen, H. (2012) "Pellicer y la prensa de su tiempo". Janus: estudios sobre el Siglo de Oro 1, pp. 55-88.

Ettinghausen, H. (2015) "Notes on the Layout and Illustration of Front Pages in the Pre-Periodical Printed News". In: H. Ettinghausen, How the Press Began. The Pre-Periodical Printed News in Early Modern Europe. A Coruña: Janus, pp. 267-281

Gallego Gallego, A. (1990) Historia del grabado en España. Madrid: Cátedra.

González Fandos, P. (2018) "Gómez de Blas, impresor en Sevilla. De su vida y testamento". Revista Internacional de Historia de la Comunicación 10, pp. 175-198. doi: https://doi.org/10.12795/ rihc. 2018.i10.09

Graham, H. and Kilroy-Ewbank, L. G. (2018) Visualizing Sensuous Suffering and Affective Pain in Early Modern Europe and the Spanish Americas. Boston/Leiden: Brill.

Haffemayer, S. (2004) L'information dans la France du XVIIe siècle. la 'gazette' de Renaudot de 1647 a 1663. Paris: Honoré Champion.

Infantes, V. (1996) “¿Qué es una relación? (Divagaciones varias sobre una sola divagación)”. In: M. C. García de Enterría, H. Ettinghausen, V. Infantes and A. Redondo, eds., Las relaciones de sucesos en España (1500-1750). Actas del Primer Coloquio Internacional (Alcalá de Henares, 8, 9 y 10 de junio de 1995). Alcalá de Henares: Publications de la Sorbonne, Servicio de Publicaciones de la Universidad de Alcalá, pp. 203-216.

Infelise, M. (2001) Prima dei giornali. Alle origini della pubblica informazione. Roma: Laterza.

Judson, J. R. (1978) Book illustrations and title-pages. London/Philadelphia: H. Miller.

López Poza, S. (2008) "Signos visuales de identidad en el Siglo de Oro". In: A. Azaustre Galiana and S. Fernández Mosquera, coords., Compostella aurea. Actas del VIII Congreso de la Asociación Internacional del Siglo de Oro (AISO), Santiago de Compostela, 7-11 de julio de 2008. Santiago de Compostela: Universidad de Santiago de Compostela, pp. 61-94.

Mínguez, V. (1999) "Imágenes para leer: función del grabado en el libro del Siglo de Oro". In: A. Castillo Gómez, comp., Escribir 
y leer en el siglo de Cervantes. Barcelona: Gedisa, pp. 255-283.

Morison, S. (1932) The English newspaper: some account of the physical development of journals printed in London between 1622 and the present day. Cambridge: Cambridge University Press.

Pena Sueiro, N. (2001) "Estado de la cuestión sobre el estudio de las Relaciones de sucesos". Pliegos de Bibliofilia 13, pp. 43-66.

Pena Sueiro, N. and Fernández Travieso, C. (2013) "La edición de relaciones de sucesos en español durante la Edad Moderna: lugares de edición e impresores". In: P. Cátedra and M. E. Díaz Tena, eds., Géneros editoriales y relaciones de sucesos en la Edad Moderna. Salamanca: SEMYR, pp. 125-145.

Peñalver Gómez, E. (2019) La imprenta en Sevilla en el siglo XVII, $\mathrm{PhD}$ thesis defended at the University of Seville.

Petta, M. (2016) "War News in Early Modern Milan: The Birth and the Shaping of Printed News Pamphlets". In: J. Raymond and N. Moxham, eds., News Networks in Early Modern Europe. Boston/Leiden: Brill, pp. 280-304.

Pettegree, A. (2014) The Invention of News: How the World Came to Know About Itself. London: Yale University Press.

Pike, R. (1966) Enterprise and Adventure: the Genoese in Seville and the Opening of the New World. Ithaca: Cornell University Press.

Prieto Pérez, J. O. (2015) "El Marquesado de Estepa. Paradigma de los nuevos señoríos”. In: J. A. Filter Rodríguez, ed., La nobleza en el Reino de Sevilla durante el Antiguo Régimen (siglos XIII-XVIII). Actas de las XI Jornadas de Historia y Patrimonio sobre la provincia de Sevilla. Sevilla: Diputación Provincial de Sevilla, pp. 293-306.
Reyes Gómez, F. de los (2010) "La estructura formal del libro antiguo", Paratesto 7, pp. 9-61.

Raymond, J. and Moxham, N., eds. (2016) News Networks in Early Modern Europe. Boston/Leiden: Brill.

Ruiz, E. (2011) La balanza y la corona: la simbólica del poder y los impresos jurídicos castellanos. Madrid: Ollero y Ramos.

Salas Almela, L. (2013) The Conspiracy of the Ninth Duke of Medina Sidonia (1641): An Aristocrat in the Crisis of the Spanish Empire. Boston/Leiden: Brill.

Schudson, M. (1994) The Power of News. Cambridge MA: Harvard University Press.

Smith, M. (2001) The title-page, its early development, 1460-1510. London/New Castle: Oak Knoll Press.

Soto-Escobar, R. (2019) "Estilo informativo entre los siglos XVI y XVII: los manuales epistolares". Estudios sobre el Mensaje Periodístico 25 (2), pp. 1103-1119. doi: https://doi.org/10.5209/ esmp. 64828

Soto-Escobar, R. and Espejo-Cala, C. (2019) "The information sources of the first Spanish Newspapers (1618-1635): the construction of information credibility". Communication \& Society 32 (3), pp. 81-92. doi: https://doi.org/10.15581/003.32.3.81-92

Sousa, J. P. (2013) Jornalismo em Portugal no alvorecer da Modernidade. Lisboa: Media XXI.

Welke, M. and Wilke, J. (2007) 400 Jahre Zeitung: Die Entwicklung der Tagespresse im internationalen Kontext. Bremen: Edition Lumière

Wilkinson, A. S. and Ulla Lorenzo, A. 2017. A Maturing Market: The Iberian Book World in the First Half of the Seventeenth Century. Boston/Leiden: Brill. 